SH

35

. N8W7 



Copy 1

\section{FISH CULTURE} IN

\section{NOETIA OAROIIINA.}

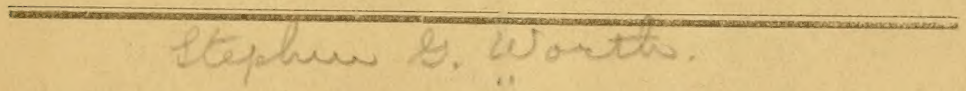


34,941 


\section{PREFACE.}

In presenting the report of S. G. Worth I call attention to section 7 of the Act creating the Department of Agriculture which charges the Board especially "With the supervision of all measures for the protection, propagation and culture of fish in the rivers and other inland waters of this State, and to this end they shall at once provide for stocking all available waters of the State with the most approved breeds of fishes." Though this Act was not ratified till as late as the 12th day of March, $18 \%$, the services of an expert were secured and a corps of young men of this State as assistants were stationed on Neuse river and the hatching of shad began. Prevailing freshets and diminutive run of shad interfered with full success of the work.

Since that very great success has been attained not only in the propagation of shad but also in the propagation and introduction of California salmon, land-locked salmon and brook trout. For the propagation of the latter varieties a cheap hatchery was built at Swannanoa Gap in Buncombe county, and two seasons of winter work have been completed. The results are embodied in the accompanying report.

Commencing only two years ago without a shad box, distributing can, or the least preparation of the necessary apparatus used in fish culture, or without a man in the State who knew the principles of the work, the people of the State may congratulate themselves on what has been attained.

I would especially note here that every effort has been officially made to prevail upon the authorities of the State of South Carolina to enjoin upon their Legislature to enact co-operative laws that our people might secure a partial benefit from the fish of streams running from this State into that. I regret to say that not the first response has ever been made. The salmon 
being more perfectly adapted to the Yadkin, Catawba, Broad and Green, over 300,000 have been placed in those waters. Without laws prohibiting permanent obstructions and a wholesale destruction of the fish south of our State line, it will be necessary to discontinue the release of more fish in those streams.

It would not only be foolish to pursue our operations there, but unfair and unjust. It would be a repetition of the abuses on the Connecticut river where money was expended by New Hampshire, Vermont and Massachusetts and the shad increased seven times their former number, while the people of Connecticut on the lower waters reaped almost the entire benefits. In the laws of Virginia they will make an exception of such streams as run into our State unless we remove the obstructions. They will place no fish into streams running into this State unless obstructions to the passage of fish are removed and fish-ways or other means of crossing dams provided. So I am informed by the Fish Commissioner of that State.

If proper laws are not enacted by our Legislature toward the protection of fish it will not and shall not be the fault of the Board under which I act. In my recent report to the General Assembly which received the unanimous approval and recommendation of the Board, I entered into the details and offered such recommendations as seem to embrace all the requirements to subserve the wants of the people of the State in this interest. The operations of the last two years have demonstrated the entire practicability of filling to its utmost capacity every stream in the State. One per cent. of the salmon released in this State are worth more than our entire out-lay has been, and one per cent. of the shad released at twenty-five cents apiece would bring over nine thousand dollars. From one end of this State to the other streams cover its face like a net-work, evincing the fact that the fishing interests can be made one of our greatest industries. Successful demonstration proves that one acre of water in New]York State is more productive than several acres of land, hence any future policy in our governmental affairs which fails to take hold of our natural advantages and restore their 
productiveness will fall short of the progressive strides of the day.

Without depending on the uncertain aid of foreign experts whose time is elsewhere in demand, we have trained young men who were born and raised here in our own State who are fitted for doing all the work within our own borders.

We need friendly and fostering legislation and with the recommendations before them it remains for the General Assembly now in session to act.

L. L. POLK, Commissioner of Agriculture. 



\section{REPORT.}

\section{HoN. L. L. POLK :}

SIR :-In accordance with your request I submit below the operations in Fish Culture in North Carolina since April 1st, 1878. My immediate presence in the execution of all the work done since that dite, has given me the alvantage of innumeriable facts which beu directly on the future of this work. But I have written to you frequently as new points developed, and in numerous conversations have so fully set forth the needs and requirements that were pressing. that I will not attempt to enter all of the details in this report. This art is so new that very few amoug us hilve hat an opportunity of looking into it suffieiently to know its requirements a to piss jucgement on past o erations. Hence, I infer, is ane the honor your honorable Board has bestowed on me in leaving the execution and the details of the work entirely in my hands. During the past twelve months, ending the 1 st of April 15\%9, we have releised in the North Carolina waters over three and one-half millions of young shad, three hundred thousand California Sulmon, fifteen thousand five hundred Land-locked Salmon from Matine, and fifty thousind Mountain or Brook Trout. All of this was done at an expense of less than three thousand dollars, and among the expenditures was a sum of not less than five hundred dollars in permanent structures and hatching and distributing apparatus, tools, \&c., now on hand, including all salaries. This sum when compared with results will bear favorable comparison with similar work done any where on the globe. To convey ar idea of the immense returns in fish culture, I will make a statement which may surprise you. Californitb Salmon attain an average weight of 20 pounds, and sell readily at twenty-five cents a pound. If we suppose that ninety-nine per cent of the three hundred thousand hatched this season are never heard from and 
that the one pereent which de return attain the average weight of other waters and hring a pries of fice cents a pound, the salmon of the past season clone will more than pay the expense of the whole seation, including the shad, Lamd-locked Salmon and Trout. The immense loses in the egrgs and fry of fish seems to have been a great foresight of nature in giring to them the gleatest mu-bearing powers of any of the rertebrate animals. A $\neq 0$ pound Salmon produces 30,010 eggs :mmutitly; the Yellow Perch (liaccoon Perch or lied-fin Tront) 20,000 to 30,000; White fish of the (reat Ialies $60,000^{\circ}$ to 80,000 ; Shad 30,000 ; Carporer 300,006; Mackerel over 500,000; 'Turbot and Cod about

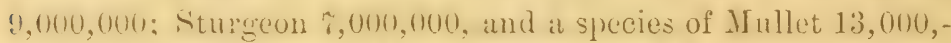
oon! These figures are from scientists and finh-culturisti, and an annual value of the fish-catch of the world, anounting to $\$ 1: 0,000,000$, will convey some idea of the millions and millions of egge annually produced from a mits of fi-h agrgregatmeg so many millions of clollars. On examinaten of the nests of the Callifornia salmon it is foumd that only eiglet pere cent of the eagers are impregnated. By the artiticial method of inurewnation we secure ninety to ninety-fice pere cent? After impregnation by the matural method the exress are left a prey te ementes of innumerable numbers. Shat eggs are expoed thre lo tive days, and our common pond lishes twersty to thirty, and din Salmon filty to seventy. After hatching, these fish are helpless, some a few days, (shat a week) some for months as in the case of Sitmom, Mountain Trout and fall-spawning tish generally. By the artificial methods they are not only almost entirely impregnater? but they are kept in cones, troughs and other ressels, and each day the dead removed and further communication of fungoid growth stopped. And when the young are ready to go out they are conveyed to heul strectins, where other fish are scarce and where cold water suppresses the numerous hosts of insects and crustacenas that abound in the lower and warmer waters. II e can see readily, that few arrire at maturity, when we recall that one single sturgeon produces seven million eggs and that a number less than ten thousand are taken aunually in the Cape Fear. Few realize the value of fish, but a moment of reflection will show that they cost us nothing, and that by replacing them in 
the waters by aiding their imperfect efforts we restore to our land at a nominal cost its millions of wealth that our streams annually bear away to the ocean. Who knows the value of the constituents of our gliding rivers, and br what means can we reclaim it? By the judicious expenditure of a few thousand dollars annually we can attain it. If our penple lcok this year for any return from what has been done, they must remember that the patient farmer sows his seed and waits till they have had time to develope and mature. No shad return in one year, and indeed no roe shad ever returned to fresh water till the third year.

Long ago fish became scarce as the population of Europe increased and fish culture there is an estublished thing. Millions of fry are annually liberated from their hatching houses, and such judicious laws have been made as to foster and protect them. In Great Britain a river yiclding in 1853 less than 2,000 Salmon was made to produce in 1866 upwards of 20,000. The Tay then leasing for $\$ 43,500$ came up in 1866 to $\$ 55,000$; and in Ireland in 1S6e one thousand tons of Salmon were transported against almost none ten years prerions. In the United States we find shad nor flourishing in the Sucramento river in Califor. nia, where they were unknown till placed there in 1871. The first results seen on the Connecticut from artificial propagation of shad increased the usual catch seven fold. Twenty-five thousund shad were taken in one locality one morning and the Northern markets were orerstocked and the price of eighteen dollars per hundred redueed to three! In that river the salmon had entirely disapeared, but in $18 \%$ ' duced and since that time suflicient $11 \mathrm{n}$ bers of 12 to 18 pounds weight have returned to justify increased operations. The fruits of past work are al:o being seen on the Delaware, Susquehamna and all other streans where the fisls have had time to mature and return. On the Mcrimack a dam of 25 feet height completely cut off the passiage of Silmon to their spawning grounds, and for thirty yeurs not one wils scen, but by introducing the fry from other streams they have fonnd that upwards of 
one throusand went orer the fishway on the same dam in the first year of their return.

Propagation by the artiticial method is an outgrowth of necessity. A hundred fears ago every stream from the St. Johns to the St. Lawrence teamed with its thousands of shad. To-day they bare become so scarce that we are compelled to resort to the largest fisheries in the land to obtain enough spawn to make our work profitable. In the absence of any data relative to the run of shad in our own waters in former days, I will state that the catch of shat on the Potomac in 1835 was $2.0500,000$, which contrasts severely with any season approaching the present. 'The alarming decrease in numbers of tish, when brought before the Congress of the Cnited States and fully imprested, at once led to the creation of a commision for the puppose of enpuiring into their decrease, and for the mstitution of measures for their increase and protection; hence originated the United State Commision of Fish and Fisheries which hat hen the great motive power and educator in this branch ever since. 'L'wentyseven statesare now actively cagaged in lecto.king their waters, and I am glad to say that with limited means we have made a very deciled becinning in North Cirulina in wo shert years. With the finest shad fishing grounds in the world, and many secluded mountain streams yet full of trout we are fully capable of supplying every county in the State with as many fish as the people can consume. In view of the fact that the shad canght in our waters sell in northern markets before the run of fish has extended into their streams, and sinee our,sales there bring double the price of theirs by supplying the early demand, it is very plain to be seen that in re-

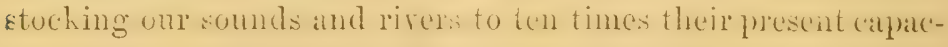
ity, we can supply every demand at home and bring into our State thousands of dollars from abroad. As the truck-farms of the south are ammully reducing the value of like prodncts on those further north, in supplying the ready demand for early vegetables and froits, so will the fisherics of dllemarle sound and other waters, in like mamner reap large cash sums of money from northern markets if the millins of eggs now an- 
nualiy wasted on the sein heaches, are only hatched and cared for.

The taking and hatching of the many millions of eggs t y the United States Commissivin last seison, was simply saring the millions, not one of which would otherwise have produced is fish,

SHAD.

Early in April, in compliance with instructions from you, I repaired to tho All, am trle sound, with a fow assistants to work in conjunction with the United States Fish Commission, that of the State of Maryland and that of Tirginia. 'The gathering of

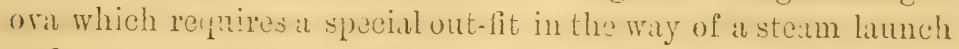
and a number of small boats and an' efficient working force of ten to twenty men, and the hatching of the ova involving a great vitriery of equipments and a goon working foree to operativ, were coirlueted entiruly under the an jios; of the Uniter States Government and the State of Maryland.

The United States Deputy Commissioner, executing the work, having an active force of distributing messenger's at commanl harriclly pishel all shipmonis possible, to tho

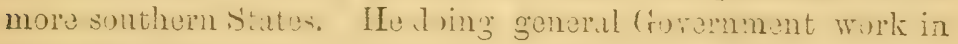

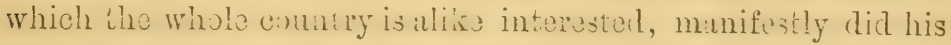
duty in making an extund 1 outlay of sovenal milli as of shinl while the weather was yet cool. At length whon the shad commenced spatring in greats numbers the young fry acemulatel faster than tho United Sates Mossengors could got them anvay and then we were granted the right to take into the interor of the State all wo conld. 13ut, young shad, aftor ten dius of age, require food, and camnot be safely carricd, and further than this, forty-two hom:s had to be consumed in making a round trip to Franklin Virginia, on onch shipnent-only seven! y-firo miles distant. I Inine it jollo vel, that the great bulk of fish on hand had necestarily to ba consignal to imansdiate waters. To get a lirger number into more suitable points of relsase will reruire a stunding force of not less than ten men who shall bo 
stationed at or near the hatchery ready at the proper moment to move half a million at a single dash. I do not call into question the wisdom of your Honorable Board in limiting the amount of expenditures on the coming spring operations; yet in view of not being able to determine the particular time at which shad begin to spawn. First, it is necessary to station a force on the sound early enough to loose nothing. Second, since we get fry for our streams only at intervals when the Cnited States men cannot move them and when rapid execution is necessary, a smaller force than ten men would he of little efficient service. Third, this work repuires character, intelligence and willingness to undergo work full of hardshij and exposure to weather, and such material, ought at least to have a recementile compens?tion; and while we placed into North Curolina watcrs nearly four million shad at a nominal cost compared with the henefits to follow, and while we will p'rompty cany out the designs of your IIongratsle Board in like manner in the work immerliately before us, it is yet a serious matter of regret that we are obliged to look calmly on at the operations of the United States work and sce annually ten to twenty million shad fry shipped out of North Carolina to replete the mater of other States, when for tro then and dollin's cenomically anplicd crery one of these conld be turned into the fine headwaters of our oun streams. No State in the workt has a better showing to fill all its steam,

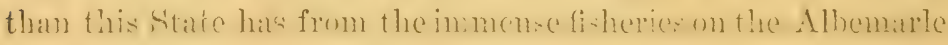
cound. A beginning has there been made in permanent hatching structures, by the erection of a tank of the very best quality with coves for hatching the eggs.

MOUNTAIN OIR BROOK TROUT.

After earnest entreaty on my part, it was agrecd last June that I should be allowed to collect as cheaply as possible some of our fine brook tront-jet abundant in our most retired western streams for spawn taking purposes. Accordingly I spent several weeks in some of the wildest monntain gorges of the State. In the more settled portions they hare become searee and some of 
the fincst procured were carried from the healwaters of Tow river at the bate of Mitchell's jeak directly up the side of the Blue Ridge within three humbed valds of the Pinnacle. I Was accompanied by a small party and we relieved each other by turns. These fish we carried on our shoulder's four miles up the Ridge and three miles down accomplishing a trip in ten hours and thirty minutes. On an arerage the water was renewed every seren minntes and when it is remembered that we had to wade the streans and follow a course that only men reared in those mountains could follow, it may well be realized that in conjunction with the highest summer heat ever known there, that the undertaking was of a serere nature.

Owing to the streams being "fished out" at so late a season as July 3rd and fish being scarce, and the high summer heat and slow transit orer the rocky and in many places nearly impassable roadds, I could not get any rast number, and of those I did get, many were lost through the list mentioned anencies. I secured over $2000 \mathrm{fish}$, but from deaths from rarious causes, including injuries in the brain from the hook, they only numbered 1400 in September. Sines then the deaths hare ceased. For the purpose of sorting these I built three cheap ponds for their accommodation. I hecan to take oral from these on the 29th day of October at the Salmon Hatehery at Swannanoa Gap. I took lut ten thousand, when the fish became so wild that they would no longer enter the spaming races, and I was obliged to stop. It was not ad risable to net them owing to the fact that the Salmon from California were hatched in the house below, and I deemerl it unsafe to stir up the bottom and send down an epidemic-producing volume of impure gases which had formed from waste meats in feeding the trout previously. I do not know what number were left in the tront but probably sixty thonsind. Ioung trout have just hatched from those eggs. Besides these the 50,000 trout eggs ordered from New Iramplime an now hitched, sare 10,000 which becams solidly frozen up in the cold wather from January and to Sth They are yet on hand at the Hatchery at Swammonoa Gap, being too young to go into the streams. 
With the knowledge attained this season, which was my first experience with trout, and with care and feeding the trout through the spring and summer and increasing their size, at least 200,000 eggs can he taken from them next fall, while the salnon are heing hatched. If we wore to purehase this number from the north they would not cost less than six humbed dollars. Farther than this the trout in the ponds will produce a greater number of egos calch seasun. Our hatching house lnilding is of the most inferior cuality, hut was constructed for experinental work and has answered all purposes so far; but as nothing but running branch water is used, its temperature is so reduced in cold weather as to freeze solid in troughs, house and ponds without incessant lation r ight and day while the cold spells prevail. The troughs, reservoir and supply troughs are common and leaky and the ice formed eighteen inches thick on one entire floor, "ren encruatehing on our oftice, freezing six inches thick and remaining a month in the bunks made for our slecpring aceommodation, and within four feet of a stove in which a fireburned night and day for weeks. I respectfully recommend that we may have a new building and at a point at which we maly get spring water and be near enough a market to buy necessaly articles withont having to pay double their ralue to get them to ns; also where we can get fish food regularly and cheaply. At at elevation of 2600 feet we may resonably look for cold weather every winter, and the house camnot be carried salely through another winter of erual severity with the present.

\section{CALIFORNIA SALMON.}

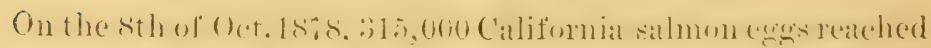
Henry's and I commenced the regular winter season with Mr. C. J. Huske, of Fayetterille, assisting. On the 9th of October an additional number of 52,500 of the eame eggs came, making a total of 367,500 . 'These eggs were allotted to North Carolina by Prof. S. F. Baird, Commisomer of Fish and Fisheries of the United States. 'They are taken annually to the number of five to seven millions on the McCloud river, Calitornia, under in- 
structions from Prof. Baird. Ifis idea has been that this salmon will ascend our warm Southem streams, and the eggs coming from the general fund cost us nothing but express charges. Last season orer two hundred and thirty thousind were turned loose in our waters and although this seatson one crate of 52,500 were almost a total loss from over-heating while en route, the rest turned out in a most gratifying manner and we released upwards of 300,000 . In the hatching ponds at Swannanoa Galp I have eight of thrse hatched last fall, and many were secu last summer in the streams in which they had been released. They are sis inches long and much more active than the mountain trout. I am reliably informed that a few of this same variety placed into Dr. D. W. C. Benbow's pond, near Greensboro, in the fall-winter of $18 \%$, measured at two years of age nineteen inches in length. At that time they had been in fresh water six months longer than nature provides, and demon itrated their power to hive eren in as warm water as our midland streams afford.

On reference to the report of the Commissioner of Fisheries of California, of $18 \% \%$, it will he found that the species has been converted into a fresh water fish when effectually cut off from the lower waters, but I am rather inclined to believe it would do su in our waters in pure, clear mountain streams only. Thus changed they attained a weight of as much as ten pounds. As before stated the California salmon attains naturally an arerage weight of twenty pounds. The larger ones attain forty, sixty and sometimes serenty pounds. The young renuin in fresh water about eighteen months and then pass down to the sea. Here they remain till grown when they return in the fall months to spawn. A large number have been seen in Atlantic rivers already, and if their introduction proves a complete success we will have at our doors the finest fish in the world. Why it shall not live here I caunot see. Full three fourths of the plants, cereals, regetables and grases on which nan and other animals live are imported. There is a vast revenue derived from salmon on rivers where they have not been recklessly destroyed. The salmon of the Columbia river, Oregon, are yet abundant and furnished a few seasons back in amounts, camned, thirteen mil- 
lion pounds. I earnestly desire that every measire ma be taken by your honorable Board to protect those now in our streams, and to allow us to continue the hatching and distributing of this valuals species each suceecting year. The number of this rariety placed in our waters in the winter season of 18 - -1 were two humdred and thirty-four thousand. They were hatched at the Swamnanoa hatchery by Mr. W. F. Page, of Tirginia, who superintended that, onr first season in salmon.

LANI-LOCKED SALMON.

The fifteen thousand five hundred salmon of this name were bronght from the Maryland State hatchery the first week in April last. 'They had been hatched at the Druid IIill Hatehery under the supervision of Maj. 'i. B. Ferguson. Those who know the excellent flatror and qualities of this and the California salmon, will appreciate the character and importance of the task we have undertaken. The land-locked salnon is not migratory in its habits, hut remains exclusively in fresh, clear and cold waters. 'Tney attain a weight of several pounds and take both the batited hook and artificial flies. For the head streams of our rivers taking rise west of Greensboro this fish seems entirely adapterl, and I respectully recommend that more attention be given it in our future operations. They can be hatched simultaneonsly with the C'alifornia salmon and moutain trout.

\section{FISH THAT OUGHT TO BE FOSTERED.}

I would respectlully call attention to the imprortance of rock fish and sturgeon. These an native fish and can be male of immense value in the streams of this State.

It may not be generally known that the rock fish remains in our streams balf of the year, they ascend in the fall and remain till the shad reason is past. From what I learn there is no doubt that their spawn can be olstained in alumdance on the Roanoke river near Weldon. The immense number of eggs found in sturgenu leads to a positive assurance that we could 
increase them to an almest unlimited extent. I do not profess any keen relish for them as food, but I have noticed that at the most successful fisheries in the State, they always were taken off and sold or caten on the beach. They subsist by suction, living on decayed matter, animal and regetable, and could exist by thousands abore the present number and not only find an abundence of food but would consume that which would not otherwise be utilized. There are some who regard sturgeon as a good article of food and others prononince it a delicacy. I am very positive that no article of food is more wholesome and the oil from them is always utilized and sells for a price that is always sufficient to insure its being boiled out. In my opinion it can be made of equal value with any other fish in our waters.

Under this head I will here state that the people of this commonwealth are making so many urgent requests for fish for private ponds, that it becomes my duty to call the fact to the attention of your Board. Acting under the requirements of the present law, creating and setting forth the operations of this part of your Department, it has been conceived to be right, to handle only such fish as were of greatest commercial value and of greatest importance to the people at large. That we should not be enabled to aid in perfecting the efforts of individuals, who have recently become enlivened to the the importance of enriching their waters, is a matter of regret. Parties all over the State have built ponds for this purpose and others who have fine sheets of water are constantly making application. In riew of the fact that many of the percoid family of fishes already in our waters, are of fine flavor and respectable size, and could with a moderate sum be propagated at a hatchery in some eastern or midland county with very great success, I take the liberty of calling the matter up, hoping that it may receive your commendation and that of the people, so that when the next General Assembly convenes we may have our field enlarged and our labors made profitable in almost erery township throughout the State. 
IS THE INTERIOR OF THE STATE ENTITLEI TO THE RESULTS OF THIS WORK?

In answer to this it may be emphatically said that without our. streams are opened to their sources, and all obstructions to the Iassage and destruction of fish removed, they cannot recerve, except in an indirect way any benefit from what we are doing. 'T'o those who occupy the large fisheries in the sounds and lower rivers and reap the "Harvest of the Sea" by hundreds of thousands, this question is of greuter importance. The decrease, now so alarmingly apparant is due, more to the obstructions alove than to any other cause. Shad and sturgeon formerly ascended the Catariha and Yadkin almost to their head waters. Nature directed them to the pure clear water, where on gravelly bottoms the eggs would successfully hatch and escape the myriarls of enemies below. By ma's agency they have been ent off and the result is sadly felt. A generall iw ryuiring all owners of dams to build a sluice-way orer ench, siter a pattern prescribed by your board is our only hope. Such a mwel as you suggest can be made to answer the oflices of its design. Existing laws regulating the construction of fish ways cannot be carried into execution, and equity preserved. It should be the duty of one individual to supervise the construction of each way, that experience in the derails may conduce to economy in their construction and that the water powers may suff $\rightarrow r$ no injurv. In an act requiring the above, there sho: Id be also the requirement that these ways shouli be kept open from February 1st to June 1st, and at all other times when watr is sufficient to allow it. I wonld respectfully call your attention to the fish waty recently invented by Col. II. MeDonald Fish Commissioner of Virginia. It is an unquestionable success, and this, many have songht after and utterly failed in. As fish naturally gro down stream into deeper watersas winter approaches, the constant and never-censing tendency is to leave above each succeding year the puny offspring of fast-growing inferior ancestry.

The dams stand as barriers and destrovers and if the remedy is not applied our annual supply will necessitrily be on the 
diminishing scale. The inportmnce of this measure bears on every inhabitant of the State and cannot be too urgently pressed. The lathors of this work are for the people and unless the dams are deprived of their objectionable feature they will be denied that, which we cannot with our powers afford them. Cooperative laws in South Carolina must be obtained or the inhabitants of the upper waters of the Yarlkin, Catawba, Broad and Green Rivers will never real the treasures of those streams. Tnleas the laws of that State regulating fishing and the removal of obstructions are enteted before the results of our work have become an object, we will never secure them. Over three hundred thousend California salmon have been released in waters rumning through that State. It would be a pity to lose all of them. With such laws and enough funds to run our work on a legitimate basis we will fill erery stream in the State. No State can boast fincr waters, besides the Chowan, Nottoway, 'Tar, Neuse, Cape Fear. Yadkin and Catawba, smaller streams fill up all the gapss between, and inlets and sounds indent a coast line for hundreds of miles. Go to the Linville, John's, Swannanoa, Tuckaseege, Nantihala, Pacolet, Green and Broad and you find waters as pure, clear and limpid as the world affords. We have now the skill and appliances to restore them to their former abundance.

In conclusion I will ask you to secure if possible a law preventing the use of explosives in the capture and destruction of fish in North Carolina waters; also to prevent the destruction of any of the salmon we have introduced into our waters, making not the capture but possession the offence. The reasons for protecting them are manifest.

Below will be found a table showing what desposition we have made of the fish released in the waters of this State. It includes some work of the United States Fish Commission, and of Mr. Frank N. Clauk and W. F. Page who hald charge of the work during the first two seasons.

I would call to your special attention the earnest and faithful labors of Chus. J. Huske, IVm. Mr. Russ and Thomas Taylor who have shown character, willingness and determination whila. aiding in the prosecution of our work. 
Special acknowledgments are due to the friends of our department ${ }^{\prime}$ at Henry's and the Swannimoa Gap without whose cheerful assistance we would not only have been constantly in many difficulties (which there were numberless) but to them is also due"the preservation of half our salmon during the freezing weather in Jamuary. 'Thanks are also due to Maj. J. W. Wilson, President of the Western North Carolina railroad and to all the officers along the line whose effective aid will be remembered. Also to the officials of the Charlotte \& A tlanta Air Time and of the Spartanburg \& Asheville railroad and to Mr. Frank Coxe of Charlotte. Also to officials of the Raleigh \& Gaston railroad'and of the Wilmington \& Weldon railroad, and to the gentlemen controlling the steamers of the Albemarle Steam Narigation Company, and to the rarious railroad officials throughout the State. In almost every locality into which our operations have taken us we have met with cordial and enthusiastic support from citizens of all classes.

To Dr. W. R. Capehart is due much of our success on the Albemarle Sound. His efforts to concentrate operations at his fisheries were supported by his untiring efforts to make our work a success.

I am respectfully yours,

S. G. WORTH. 


\title{
APPENDIX.
}

\section{DISTRIBUTION OF FRY.}

\author{
SHAD.*
}

Prior to the establishment of this department, the United States Fish Commission distributed to our waters, as follows:

May, 1873, Neuse River, May, 1876, Neuse River, June, 1876, Catawba River, 43,000 98,000 72,000 SEASON OF 1877-'78.

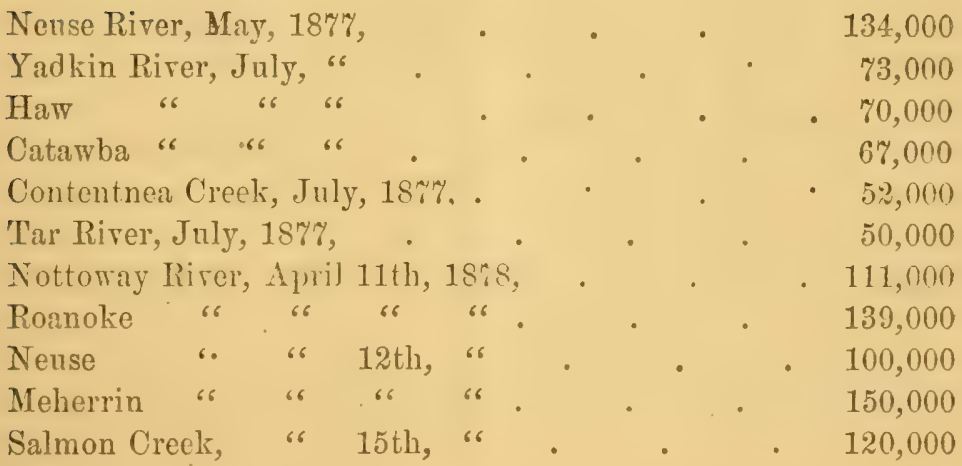

* The secmingly undue proportion released in the vicinity of Aroca was unavoidable. The young fry had to he transported a distance of about eighty miles by water to reach a railroad, and it employed the time of the messengers, day and uight, to keep the hatcheries clear. The run and catch of the snawners was affected greatly by the state of the weather, A heavy catch, especially towards the close of the scason, would sometimes occur when the boxes and apparatus were employed to their fullest capacity, and if the steamboats and messengers were not at hand, the fry had to be released to make room for the new supply of eggs. 
Neuse River, April 20th, 18\%8, . . . 50,000

Tar " " $22 \mathrm{~d}$, " . . 100,000

Salmon Creek, " " . . . 800,000

" " 25th, " . . 200,000

"Chorvan River, " 25th, " . . . 200,000

Albemarle Sound, " 25th, " . . . 115,000

Roanoke River, " 26th, " . . . 250,000

Salmon Creek, "

Albemarle Sound, " 26th, " . . . 70,000

† Six Runs, N. E. Cape Eear, April 26th, 1878 • 100,000

† Goshen Creek, X.. F. Cape Fear, April 26th, 18\%8, $\quad 100,000$

Salmon " April 28th, 1878, . . 300,000

" " " $" 29$ th, " . . . . 18,000

" " " 6 " 30 th, . . . . 45,000

Tar River, May 2d, . • . . 150,000

Yadkir Rivel, June Sth, . . . . 50,000

Catawba River, June 10th, . . . 50,000

Making a total of

CAIIFORNIA SALMON-WINTER OF 187\%-'Y8.

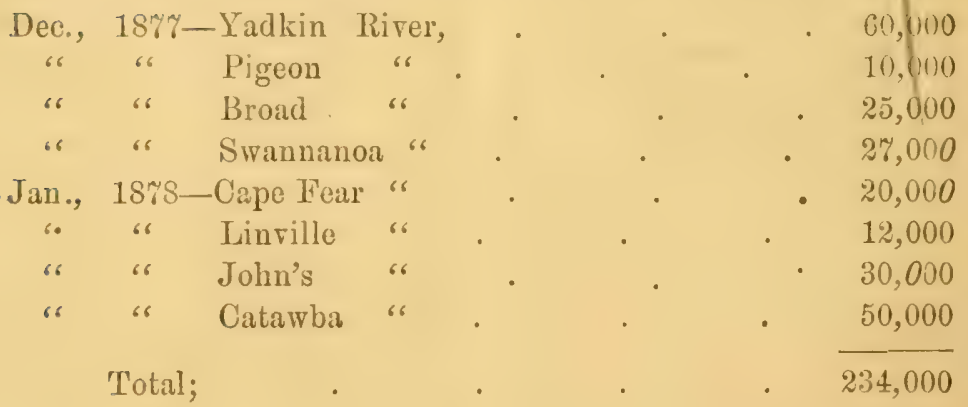

t The only accessible points of release. 
CALIFORAIA. SALMON-WINTER OF 1878-'79.

To Green River, on the S. \& A. Railroad, . 30,000

"Broad " at the mouth of Reedy Patch Creek, 45,000

"Linville " near Bridgewater, . 30,000

"John's " 12 miles from Morganton, . 30,000

"Yadkin " at Patterson's, . . . 60,000

"Deep " " . . 6 . 65,000

"Town Creek, at Germanton, . . . 20,000

"Dan River, near Danbury, . . . 20,000

Total, $\quad 300,000$

LAND-LOCKED SALMON-APRIL 5TH, 1878.

April, 1878-John's River, . . 1,000

" " Linville " . . . . 4,400

" " Mayo " $"$ " . $\quad 3,000$

" " " Dan " . . 3,000

Ponds near Charlotte. $\quad$. $\quad$. 500

" " G Greensboro, . . . 2,000

" " Morganton, . . . . . 600

" " . . . . . 1,000

Total, $\quad$. $\quad$. $\quad$. $\quad$. $\quad 15,500$

NOTES ON TIE CONSTIRUCTION OF PRIVATL FISII PONDS.

HoN. L. L. POLK:

Sir:-In obedience to your request to furnish some practical hints about the construction and management of prirate fish ponds I will make a few brief suggestions. The numerous letters you have received show a general interest throughout the State, but this is especially the case in the middle section.

When popular opinion becomes stronger in faror of fish cul- 
cule, better facilities will be offered fur the attainment of improved breeds for stocking ponds. At present it is not only impracticable to obtain suitable fry for this purpose, but there are very few who know how to undertake stocking with native fish. The conditions to be preserved are these:

Dams that will stand.

Small areas of water.

Introduction of limited varieties of fish.

Ability at all times to draw off the water.

Preparation of gravelly places for spawning.

Introduction of water plants.

Protection.

Drive wooden piling to build the dam on and make a wasteway suficient to carry all surplus water. Protect the waste-way with wire netting. In most instances it does not matter if the bottom of the pond is muddy and especially in the case of bream and blue perch. All the banks several feet out from the water's edge and foot under the water should be seraped elean to the sand with a hoe to dislodge crawfish, terrapins, and snakes. For ordinary purposes small ponts are preferahle. Where one or a number of these can be arranged on clear sandy streams a single variety may be introduced into cach and the young annually removed to larger ponds. The great loss in fish is in the egre. I single rariety in a small s. of an acre pond can increase and aroid duredations of other fish. Our native pereh deposit twenty to thirty thousund egge. No cfiectual means of exterminating the juck ath can be need, except the careful and thorongh preparation of a flood gate of medium size, protected over the face of out-flow with wire cloth. Every two years the water should be lowered and the fish sorted out, and jack fish and pike remorert. I beliere jack fish eses are carrical by some merhanical means into varions waters, as perhalps by clinging to the feet of water-fowl.

Gravel or sand beds in the shallow water near the inlet will

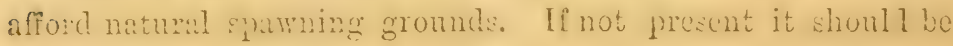
put there.

Water plants affort numberless insects and should be intro- 
duced from neighboring places. They are woll known and easily obtained.

King-fishers, herrons and other birds will only be kept away by locating in a frequented place.

The black perch is found on the Yadkin, Catawba and other western steams and will make a success in ponds. Also the large trout, chub, or green bass will pay. In the middle and lower sections the white perch, is generally present in the main streams. Wherever it is found in ponds it attains a size of one to two pounds. In the lower portion of the State I would unhesiattingly recommend this and the brean and blne perch above all others. Any of these are excellent as food and have firm flesh. Many other fine perch are susceptible of cultivation and can be raised in pouds with slight atrention. A pond on the plantation of Mr. Rowell near Wilmington contains a very surprising number of fish in a very limited space. There are eleven varieties in the pond or there wonld bo a greater number. He gives them a few grass-hoppers, abont once a week, and the oneeighth acre iu the pond would furnish a considerable family the year round. The young fist are at times removed to his mill pond.

Willow trees or others that attract insects should be plinted near fish ponds.

No bettel food than catterpillars can be found. All the perch and chub are fond of mulberries-the cheapness of which renders them important.

Three or four small ponds are greatly preferred to one large one.

In introducing fish into a pond to answer as food for larger ones the smaller varieties of perch are to be preferred.

There is no work which treats fuliy on this subject, but my own knowledge of what has been accomplished in this way shows that fish of any variety placed into a pond and not entirely neglected will prove a source of pleasure and profit.

Large fish cannot be carried safely withoutusing very large buckets or barrels and by applying changes of water. In carrying them in warm weather frequent changes are necessary, but sudden changes of temperature must be avoided. When a 
change is made, it is better to remove only a portion of the water and make changes oftener. With care they can be carried a number of hours without material loss.

Yours respectfully,

S. G. WORTH。 



\section{Hollinger Corp.} $\mathrm{pH} 8.5$ 